\title{
Introduction to the special issue: an international partnership in vocational psychology and career guidance practice
}

\author{
Raoul Van Esbroeck - Donna Palladino Schultheiss • \\ Jerry Trusty $\cdot$ Paul Gore
}

Published online: 7 April 2009

(C) Springer Science+Business Media B.V. 2009

\begin{abstract}
This thematic issue of the International Journal for Educational and Vocational Guidance includes a selection of papers presented at the IAEVG-SVPNCDA Symposium, entitled "Vocational Psychology and Career Guidance Practice: An International Partnership". The articles in this special issue deal with topics that highlight the interconnection between vocational psychology and career guidance. The authors, because of their different geographical and cultural backgrounds, address these points from their own perspectives. The outcome of the general discussion that centred on these topics at the International Symposium is jointly published in a special issue of the Career Development Quarterly, Vol. 57, No. 4.
\end{abstract}

Résumé. Introduction au Numéro Spécial: un partenariat international entre psychologie de l'orientation et pratique de l'orientation de carrière. Cette édition thématique de l'International Journal for Educational and Vocational Guidance comporte un choix d'articles présentés au colloque de l'IAEVG-SVPNCDA intitulé "Psychologie de l'orientation et pratique de l'orientation de carrière : un partenariat international". Les articles de cette édition spéciale concernent des thèmes qui font ressortir l'interconnexion entre la psychologie de l'orientation et l'orientation de carrière. Les auteurs, en raison d'horizons géographiques et

\footnotetext{
R. Van Esbroeck ( $\square)$

Faculteit Psychologie en Educatiewetenschappen, Vrije Universiteit Brussel,

Pleinlaan, 2, 1050 Brussel, Belgium

e-mail: rvesbroe@vub.ac.be

D. Palladino Schultheiss

Cleveland State University, Cleveland, $\mathrm{OH}$, USA

J. Trusty

Penn State University, University Park, PA, USA

P. Gore

University of Utah, Salt Lake City, UT, USA
} 
culturels différents, abordent ces matières de leur propre perspective. Les résultats de la discussion générale qui a porté sur ces thèmes au Colloque international sont conjointement édités dans un numéro spécial du Career Development Quarterly, Vol. 57, No 4.

Zusammenfassung. Vorwort zur Sonderausgabe: Eine internationale Partnerschaft von Berufspsychologie und Beruflicher Beratung. Diese thematische Sonderausgabe des Internationalen Journals für Bildungs- und Berufsberatung umfasst eine Auswahl von Vorträgen, die auf einem Symposium vorgestellt wurden, das gemeinsam von der Internationalen Vereinigung für Schul- und Berufsberatung (AIOSP), der amerikanischen Gesellschaft für Berufspsychologie (Society for Vocational Psychology - SVP) und der amerikanischen Nationalen Vereinigung für Berufsberatung (National Career Development Association - NCDA) unter dem Titel „Berufspsychologie und Berufliche Beratung: Eine internationale Partnerschaft" veranstaltet wurde. Die in dieser Sonderausgabe zusammengestellten Artikel stellen die vielfältigen Zusammenhänge zwischen Berufspsychologie und Beruflicher Beratung dar. Wegen ihrer unterschiedlichen geografischen und kulturellen Hintergründe behandeln das Thema aus ihren persönlichen Blickwinkeln. Die Ergebnisse der umfassenden Diskussionen, die sich auf dem internationalen Symposium um diese Themen entwickelte, wird gemeinschaftlich in einer Sonderausgabe der Zeitschrift Career Development Quarterly, Jahrgang 57, Heft 4, veröffentlicht.

\section{Resumen. Introducción al Número Especial: Colaboración entre la Psicología} Vocacional y la Práctica de la Orientación profesional en el ámbito Internacional. Este número monográfico de la Revista Internacional de Orientación Educativa y Profesional incluye una selección de artículos presentados en el Simposio de la AIOEP-SVP-NCDA titulado "Psicología Vocacional y Orientación para la Carrera en la práctica: una colaboración en el ámbito Internacional”. Estos artículos abordan temas que resaltan la interconexión entre la Psicología vocacional y la orientación para la carrera. Dada la diversidad cultural y distinta procedencia geográfica de los autores, los temas son tratados desde múltiples perspectivas. El resultado de la discusión general que se llevó a cabo sobre estos tópicos en el Simposio Internacional se ha publicado conjuntamente en un número especial del Career Development Quarterly, Vol. 57, No. 4.

Globalization processes and information technology have significantly changed the way people work. Vocational psychology is challenged to respond to the vast effects these advances have had on the organization of work and work roles. Vocational guidance is being called upon to confront an important series of new challenges that require careful evaluation of the validity of our theoretical models, research and practice methods, and the emerging needs of our clients.

Unfortunately, these new challenges are not tackled by a unified group of vocational psychology and guidance specialists. The broad field has been split into several wings, each one with its own agenda and priorities that lead to the construction of different "homes" (Savickas \& Baker, 2005). The splits between 
vocational specialists working in the field of counselling vs. organizational psychology, the methodological differences between qualitative vs. quantitative approaches, etc., are more and more recognised (Van Esbroeck, 2007). In particular the "schism between career theory and practice" (Savickas \& Walsh, 1996, p. xi) is one of the long recognised splits. These splits weaken the efforts of all groups within the vocational guidance movement to find adequate responses to the new challenges.

During the concluding session at the 2005 Society for Vocational Psychology (SVP-section of the Society of Counseling Psychology of the American Psychological Association) biennial conference held in Vancouver, Canada, the gap between practice and theory was mentioned several times as one of the priority topics and concerns that needed to be worked upon. It was also at that conference that the one-time presidents of SVP and the National Career Development Association (NCDA), David Blustein and Janet Lenz, the SVP president-elect Paul Gore, together with Raoul Van Esbroeck, of the International Association for Educational and Vocational Guidance (IAEVG) and chair of the first joint IAEVGNCDA Symposium, discussed ways of responding to these concerns. Because of the success and outcomes of a first International Symposium organised by IAEVG and NCDA held in July 2004 in San Francisco, California, the idea of a new joint symposium sponsored by all three organizations was put forward. This first joint international symposium made a significant contribution to the establishment of a network of scholars and practitioners concerned with the internationalization of educational and vocational guidance and meeting the needs of workers in a global economy.

The boards of IAEVG, SVP and NCDA supported this idea and each appointed three representatives to form a Planning Committee: Salvatore Soresi, Raoul Van Esbroeck, Jean Pierre Dauwalder (IAEVG); David L. Blustein, Paul Gore, Donna Palladino Schultheiss (SVP); and Spencer Niles, Darrell Luzzo, Jane Goodman (NCDA).

This planning committee met for the first time in 2006 at the 26th International Congress of Applied Psychology in Athens (Greece). The Italian representatives in the group, Salvatore Soresi and Laura Nota, both of the University of Padova, accepted to organise this Symposium adjacent to the IAEVG 2007 International Conference. These colleagues were appointed as the Symposium chair and co-chair. To promote an international exchange of ideas on the role of vocational psychology and career guidance in our global society, the theme selected for the 2007 IAEVGSVP-NCDA Symposium was Vocational Psychology and Career Guidance Practice: An International Partnership.

The aim of this symposium was to bring together a limited group of scholars and practitioners from around the globe to discuss some of the most pressing issues facing vocational guidance today and to establish shared goals and lines of research and intervention. The specific goals of this symposium were to discuss thematic approaches to global issues, the changing nature of work accelerated by advances in information technology, the need for practitioners to adapt to better meet the changing needs of people throughout the world, and to strengthen global partnerships between co-operating organizations. The organising committee opted 
to use the same format as in the IAEVG-NCDA International Symposium in San Francisco, California, in 2004. In line with the ancient Greek tradition, it was decided that the one-day symposium would be built around eight discussion groups and that the exchange of ideas would be the main goal. In these groups, only a limited number of invited and selected papers would be presented as a starting point for further in-depth discussions. The plenary session would be limited to a short introduction to the general theme given by Raoul Van Esbroeck and a keynote by Annelies Van Vianen on "Adaptable Careers", a topic in line with the present global societal developments. The Symposium would end with conclusions presented jointly by Donna Palladino Schultheiss and Raoul Van Esbroeck.

Taking into account the outcomes of the 2004 IAEVG-NCDA Symposium and recent societal developments, the following themes were chosen:

- Vocational psychology and new challenges (Chair: D. Blustein)

- Problems and needs for interdisciplinary interactions in vocational guidance (Chair: D. Schultheiss)

- Models for the analysis of individual and group needs (Chair: W. Patton)

- Vocational guidance requests within the international scene (Chair: Jane Goodman)

- Procedures, suggestions and instruments for assessment (Chair: Paul Gore)

- Procedures, suggestions and instruments for intervention (Chair: Darrell Luzzo)

- Procedures to verify the efficacy of vocational guidance programmes (Chair: J.P. Dauwalder)

- Training of career guidance researchers and practitioners (Chair: Spencer Niles)

Within these themes, all participants in the discussion, each of them with their specific knowledge and background and belonging to so-called different wings, are expected to work towards one goal, to listen to each other and to see how they can transcend the so called borders. If this goal could be realised the different "homes" might become different "rooms", with many doors leading to each other and forming one large "house", which will be the home of all vocational psychology and career guidance specialists and practitioners.

The keynote presentation and the outcomes of the discussion groups at the international symposium have been published in a companion volume to this issue, namely Volume 57, Number 4 of The Career Development Quarterly. This special issue of the International Journal for Educational and Vocational Guidance includes six of the papers presented in the discussion groups. The selection is because of the limitation on the number of pages - only a limited sample of the contributions in the discussion groups. Several other papers, however, will be translated into Italian and published in the proceedings of the 2007 IAEVG conference that was organised immediately after the symposium (see Nota \& Soresi, in press). Most of the articles in this volume are of a rather more theoretical and reflective nature. Only one experimental article is included.

The first article in this issue, by Mary Sue Richardson, on "Another way to think about the work we do: Counseling for work and relationship", was presented in the group that worked on "Vocational psychology and new challenges". She proposes a new paradigm for the fields of vocational psychology and guidance. Central to this 
paradigm is to replace the notion of career by work and to expand the attention for the social context from work to the broader occupational and personal domains. In this, she is in line with the growing attention given to the role of the broader environment in career development.

The two following contributions, both presented by the group working on "Problems and needs for interdisciplinary interactions in vocational guidance", are also more reflective. Ladislav Valach and Richard Young, in their article on "Interdisciplinarity in Vocational Guidance: An Action Theory Perspective", present some ideas to better understand the specificities and difficulties of interdisciplinary research in vocational guidance. Their approach is based on the action theory perspective. Audrey Collin, in her paper on "Multidisciplinary, Interdisciplinary, and Transdisciplinary Collaboration: Implications for Vocational Psychology", deals with the issue of how several forms of interdisciplinarity can contribute to actions in vocational psychology. In particular the role of interpersonal relationships in such a collaboration is stressed.

Justin Perry, in his presentation on "A social action, mixed methods approach to vocational guidance efficacy research", in the group working on "Procedures to verify the efficacy of vocational guidance programmes", proposes a new method in guidance efficacy studies. He concludes that despite many barriers, of which some were highlighted in his paper, the combined social action/mixed method approach should be supported. The use of such a method in efficacy studies may be an ambitious goal, but the advantages are obvious.

From the presentations in the group on "Vocational guidance requests within the international scene", one contribution was accepted. Alessandro Lo Presti wrote an article on "Snakes and ladders: Stressing the role of meta-competencies for postmodern careers". This is clearly a contribution that is part of I/O psychology room. The labelling is justified by the analysis of and reference to post-modern definitions as protean, boundaryless and intelligent careers. But also the attention given to the role of meta-competencies in the career self-management makes it very clear.

The final article in this issue, by Annamaria Di Fabio and Letizia Palazzeschi on "Emotional intelligence, personality traits and career decision difficulties", is the only experimental contribution. It was presented in the group working on "Procedures, suggestions and instruments for intervention". This study arrived at some interesting results. Though there is quite some debate on the question of whether the construct of emotional intelligence is a new construct or just a nonconstruct overlapping with personality traits, the authors bring data to support those who argue in favour of the EQ construct. They find, e.g., that EQ can account for a larger part of the variance in career decision difficulties in addition to personality traits. Interesting results that deserve to be studied further.

All contributions support from their specific points of view the idea that the "house" of vocational psychology and career guidance is a complex structure with many rooms. They also prove, however, that interactions between the different rooms are possible. It only requires willingness to listen and openness to recognise differences. Hopefully, this issue of the International Journal for Educational and Vocational Guidance together with the companion issue of the Career Development 
Quarterly will give the reader a good impression of the results achieved at the IAEVG-SVP-NCDA 2007 International Symposium in Padova, Italy.

\section{References}

Nota, L., \& Soresi, S. (Eds.). (in press). Nuove sfide per l'orientamento scolastico-professionale [New challenges for vocational guidance]. Firenze: Organizzazioni Speciali-Giunti.

Savickas, M. L., \& Baker, D. B. (2005). The history of vocational psychology: Antecedents, origin, and early development. In W. B. Walsh \& M. L. Savickas (Eds.), Handbook of vocational psychology (3rd ed., pp. 15-50). Mahwah, NJ: Lawrence Erlbaum Associates.

Savickas, M. L., \& Walsh, W. B. (1996). Introduction: Toward convergence between career theory and practice. In M. L. Savickas \& W. B. Walsh (Eds.), Handbook of career counseling theory and practice (pp. xi-xix). Palo Alto, CA: Davies-Black.

Van Esbroeck, R. (2007). A new disciplinary home for vocational psychology: A house with many rooms. International Journal for Educational and Vocational Guidance, 7(3), 203-206. 